\title{
man \\ Retail Packaging Affects Colour, Water Holding Capacity, Texture and Oxidation of Sheep Meat more than Breed and Finishing Feed
}

\author{
Minh Ha ${ }^{1, *(\mathbb{D})}$, Robyn Dorothy Warner ${ }^{1}\left(\mathbb{D}\right.$, Caitlin King ${ }^{1}$, Sida $\mathrm{Wu}^{1}$ and Eric N. Ponnampalam ${ }^{2}$ \\ 1 School of Agriculture and Food, Faculty of Veterinary and Agricultural Sciences, The University of \\ Melbourne, Parkville, VIC 3010, Australia; robyn.warner@unimelb.edu.au (R.D.W.); \\ caitlink1@student.unimelb.edu.au (C.K.); sidaw1@student.unimelb.edu.au (S.W.) \\ 2 Animal Production Sciences, Agriculture Victoria Research, Department of Jobs, Precincts and Regions, \\ Bundoora, VIC 3083, Australia; Eric.Ponnampalam@agriculture.vic.gov.au \\ * Correspondence: minh.ha@unimelb.edu.au
}

Citation: Ha, M.; Warner, R.D.; King, C.; Wu, S.; Ponnampalam, E.N. Retail Packaging Affects Colour, Water Holding Capacity, Texture and Oxidation of Sheep Meat More than Breed and Finishing Feed. Foods 2022, 11, 144. https://doi.org/10.3390/ foods11020144

Academic Editor: Rubén Domínguez

Received: 14 December 2021

Accepted: 27 December 2021

Published: 6 January 2022

Publisher's Note: MDPI stays neutral with regard to jurisdictional claims in published maps and institutional affiliations.

Copyright: (C) 2022 by the authors. Licensee MDPI, Basel, Switzerland. This article is an open access article distributed under the terms and conditions of the Creative Commons Attribution (CC BY) license (https:// creativecommons.org/licenses/by/ $4.0 /)$.

\begin{abstract}
This study investigated the CIELab colour, water holding capacity, texture and oxidative stability of sheep meat from different breeds, finishing feeds, and retail packaging methods. Leg primal cuts from a subset of Composite wether lambs $(n=21)$ and Merino wether yearlings $(n=21)$ finished on a standard diet containing grain and cereal hay, a standard diet with camelina forage, or a standard diet with camelina meal, were used in this study. Semimembranosus and Vastus lateralis were packaged in vacuum skin packaging (VSP), or modified atmosphere packaging with $80 \% \mathrm{O}_{2}$ and $20 \% \mathrm{CO}_{2}$ (HioxMAP), or with $50 \% \mathrm{O}_{2}, 30 \% \mathrm{~N}_{2}$, and $20 \% \mathrm{CO}_{2}$ (TrigasMAP). Packaging had a greater effect $(p<0.001)$ on $\mathrm{L}^{*}, \mathrm{a}^{*}, \mathrm{~b}^{*}$, hue, and chroma than the effects from breed and finishing feed. Purge loss was affected by packaging. Cooking loss was affected by breed for Semimembranosus and packaging for both muscle types. HioxMAP and TrigasMAP increased WBSF and Texture Profile Analysis hardness of the meat compared to VSP. Lipid oxidation, assessed by TBARS, were lower in camelina forage or camelina meal supplemented diets and TrigasMAP compared to standard diet and HioxMAP, respectively. Total carbonyl and free thiol content were lower in VSP. Thus, supplementing feed with camelina forage or meal and lowering oxygen content in retail packaging by TrigasMAP or VSP are recommended to ensure optimal sheep meat quality.
\end{abstract}

Keywords: Merino; composite; modified atmosphere packaging; trigas; camelina; lipid oxidation; colour stability; meat

\section{Introduction}

In the sheep meat supply chain, quality traits such as colour, water holding capacity, texture, and oxidative stability are determined by various factors, including breed, finishing feed, and retail packaging method. High-oxygen modified atmosphere packaging (HioxMAP), using $70-80 \% \mathrm{O}_{2}$ and $20-30 \% \mathrm{CO}_{2}$, is a common meat retail packaging method due to its ability to maintain the "fresh" cherry red colour of meat. However, extensive research has shown an increased oxidation and lower eating quality of meat in HioxMAP compared with vacuum skin packaging (VSP) [1-3]. Trigas modified atmosphere packaging (TrigasMAP) is a more recently developed method in which oxygen is partially substituted with an inert gas, e.g., nitrogen, and has shown promising results in improving the eating quality and shelf life of meat [4].

The finishing feed of livestock is another factor affecting the quality of meat through altering the antioxidant activity in post-mortem muscles. The incorporation of antioxidants, such as vitamin E, or antioxidant-rich pasture crops were shown to result in reduced lipid oxidation and improved eating quality [5,6]. The use of oil crops and meals as animal feed supplements from the Brassica family, particularly camelina (Camelina sativa) has recently 
gained attention in improving animal productivity and carcass value [7]. Camelina seed is known to contain essential fatty acids, such as alpha-linolenic acid and different phenolic compounds such as flavonoids and proanthocyanidins, which provides an opportunity to improve the oxidative stability of meat [8].

Animal breed or the genetic background is also known to influence the sheep meat quality. For example, pure Merino sheep is believed to produce meat that is less tender or darker in colour compared with meat from crossbred sheep. The differences in texture and colour are associated with carcass fatness, muscle glycogen concentration, muscle iron concentration, and/or post-mortem chill effects $[9,10]$.

Many studies have demonstrated the effect of the three supply chain factors of breed, feed and packaging individually. However, little is known about their interactive effect or the extent to which each factor affects meat quality. Thus, the aim of this study was to investigate the quality of sheep topsides (Semimembranosus) and knuckles (Vastus lateralis) from Merino yearlings and Composite wether lambs, finished on three different diets (standard diet; standard diet supplemented with camelina forage; or standard diet supplemented with camelina meal), and packed in three retail packaging methods (VSP, HioxMAP or TrigasMAP). The CIELab colour, water holding capacity, texture, lipid oxidation and protein oxidation were measured.

\section{Materials and Methods}

\subsection{Animal Housing and Feeding}

Feeding experiments were conducted at the Agriculture Victoria Research, Hamilton Centre, Hamilton, VIC, Australia. All animal procedures were conducted in accordance with the Australian code for the care and use of animals for scientific purposes (National Health and Medical Research Council 2013). Animal ethics approval was granted by the Department of Jobs, Precincts and Regions (DJPR) Agricultural Research and Extension Animal Ethics Committee (AEC Code No: 2016-17). Details of the experimental design, feeding of animals, and slaughter procedures were described previously [7]. In brief, a subset of maternal Composite wether lambs $(n=21)$ and Merino wether yearlings $(n=21)$ kept in different pens selected based on their final liveweights were used for this study. The primal cuts were from animals randomly allocated to three finishing feeds: a standard pelleted diet containing grain and cereal hay (SPD), a pelleted mixture diet containing $15 \%$ camelina forage hay (SCF), or a pelleted mixture diet containing $8 \%$ camelina meal (SCM). Diets were formulated using the ingredients available in the major sheep producing regions. The metabolizable energy $(\mathrm{ME})$ and crude protein concentrations of the diets were managed to be $10-11 \mathrm{MJ} \mathrm{ME} / \mathrm{kg}$ dry matter and $14-15 \%$ crude protein.

\subsection{Slaughter Procedure and Collection of Sheep Primals}

The animals were transported approximately $250 \mathrm{~km}$ using a semi-trailer to a commercial abattoir and slaughtered after $18 \mathrm{~h}$ in lairage. At 5 days post-mortem, legs from the left side of the animals were collected. Topsides and knuckles from the legs were boned from the legs. The muscles were vacuum-packed using a Multivac C450 (Sepp Haggenmüller $\mathrm{GmbH} \&$ Co., Wolferschwenden, Germany) with Cryovac ${ }^{\circledR}$ vacuum pouches (PA/PE 70, Sealed Air, Fawkner, VIC, Australia) with an oxygen permeability less than $65 \mathrm{cc} / \mathrm{m}^{2} / 24 \mathrm{~h}$ and water transmission less than $5 \mathrm{~g} / \mathrm{m}^{2} / 24 \mathrm{~h}$. The vacuum-packed muscles were frozen at $-20{ }^{\circ} \mathrm{C}$ for 6 weeks.

\section{3. pH, Cutup, Packaging and Retail Display}

Following thawing at $2{ }^{\circ} \mathrm{C}$ for $24 \mathrm{~h}$, meat cutup and packaging were conducted at approximately $6^{\circ} \mathrm{C}$. Prior to cutup, the $\mathrm{pH}$ of the muscle was measured using a spear-head $\mathrm{pH}$ probe attached to a WP-80 pH-mV-temperature meter (TPS Pty Ltd., Brisbane, QLD, Australia). Semimembranosus and Vastus lateralis were extracted from the topsides and knuckles. The muscles were cut into three sections from the anterior and randomly allocated to VSP, HioxMAP, or TrigasMAP packaging treatments. All packaging was conducted using a Multi- 
vac T200 (Sepp Haggenmüller GmbH \& Co., Wolferschwenden, Germany). Meat samples were placed on a cello soaker pad (130 mm $\times 90 \mathrm{~mm}$; CBS, Carrum Downs, Australia) inside a black Cryovac ${ }^{\circledR}$ MAP packaging tray (T0D0901C $170 \mathrm{~mm} \times 223 \mathrm{~mm}$, Sealed Air, VIC, Australia). The trays were sealed with a Biaxially Oriented PolyAmide/Polyethylene/Ethylene vinyl alcohol-based film (OTR $15 \mathrm{cc} / \mathrm{m}^{2} / 24 \mathrm{~h}$ ). The gas composition in HioxMAP was $80 \% \mathrm{O}_{2}$ and $20 \% \mathrm{CO}_{2}$ while TrigasMAP had $50 \% \mathrm{O}_{2}, 30 \% \mathrm{~N}_{2}$, and $20 \% \mathrm{CO}_{2}$. Vacuum skin packaging was conducted using Cryovac ${ }^{\circledR}$ Darfresh $^{\circledR}$ film (OTR $4 \mathrm{cc} / \mathrm{m}^{2} / 24 \mathrm{~h}$ ) and black Cryovac ${ }^{\circledR}$ trays (Sealed Air, Fawkner, VIC, Australia). Packaged samples were stored in a simulated retail display cabinet with LED lighting ( 310 lux, Bromic Refrigeration, Ingleburn, NSW, Australia) at $4{ }^{\circ} \mathrm{C}$ for 10 days. The samples were rotated daily between shelves to minimise the effects of variations in illumination and temperature within the retail display cabinet on the samples.

\subsection{Instrumental Colour Measurement}

After 10 days in simulated retail display, CIE L* (lightness), $a^{*}$ (redness), and $b^{*}$ (yellowness) were measured on the meat surface using a Minolta chroma meter CR-300 (Minolta Co., Ltd., Osaka City, Japan), calibrated with a white plate (no. 20733120; Y = 84.9; $\mathrm{x}=0.3171 ; \mathrm{y}=0.3240$ ). The colour of vacuum skin-packed samples was measured after a 30 min blooming at $6{ }^{\circ} \mathrm{C}$, whereas the colour of HioxMAP and TrigasMAP samples were measured immediately after the samples were removed from packaging. Duplicate colour measurements were taken on each sample. Hue angle $\left(\mathrm{h}^{*}\right)$ and chroma $\left(\mathrm{C}^{*}\right)$ were calculated using the following equations:

$$
\begin{aligned}
& \text { Hue angle }=\arctan \left(\mathrm{b}^{*} / \mathrm{a}^{*}\right) \\
& \text { Chroma }=\sqrt{\left(a^{*}\right)^{2}+\left(b^{*}\right)^{2}}
\end{aligned}
$$

\subsection{Purge and Cooking Loss}

Purge loss was expressed as the weight loss in packaging during retail display. Samples were weighed before packaging (initial weight) and after 10 days storage (final weight). Excess moisture was removed with paper towel before weighing. Purge loss was calculated using the following equation:

$$
\text { Purge loss }(\%)=(\text { weight before pack }- \text { weight after pack }) /(\text { weight before pack }) \times 100
$$

Cooking loss was measured during the cooking procedure for Warner-Bratzler shear force and texture profile analysis. Each sample was weighed before cooking. After cooking, excess moisture on the meat surface was removed with paper towel before weighing. Cooking loss was calculated as:

Cooking loss $(\%)=($ weight before cook - weight after cook $) /($ weight before cook $) \times 100$

\subsection{Warner-Bratzler Shear Force}

Warner-Bratzler shear force were measured according to Peng et al. [11]. Samples were individually placed in a plastic bag in temperature-equilibrated water baths (F38-ME, Julabo, Seelbach, Germany) set at $75^{\circ} \mathrm{C}$ and cooked to internal temperature of $71 \pm 0.5^{\circ} \mathrm{C}$. The internal temperature was monitored using T-type thermocouples inserted to the middle of meat samples and the thermocouples were connected to a Grant Squirrel Series 2020 datalogger (Grant Instruments Ltd., Cambridge, UK). After cooking, the samples were chilled in an ice water bath for $30 \mathrm{~min}$ and stored at $4{ }^{\circ} \mathrm{C}$ overnight. Six $4 \mathrm{~cm}$ long rectangular strips with $1 \mathrm{~cm} \times 1 \mathrm{~cm}$ cross section area were obtained from each sample by cutting parallel to the muscle fibres. Each strip was sheared using a Lloyd Instruments LRX Materials Testing Machine (Lloyd Instruments Ltd., Hampshire, UK) equipped with a $5000 \mathrm{~N}$ load cell and a V-shape Warner-Bratzler shear force blade at an extension rate of 
$300 \mathrm{~mm} / \mathrm{min}$. The WBSF (N) of each sample was expressed as the average peak force of measurements from the six strips.

\subsection{Texture Profile Analysis (TPA)}

Texture profile analysis was measured using a double bite compression procedure outlined previously Peng et al. [11]. A piece of meat measuring $1 \mathrm{~cm}$ in thickness was obtained from each sample. The meat was compressed twice at the same position by a 6.3- $\mathrm{mm}$ diameter plunger which was driven $8 \mathrm{~mm}$ into the sample at a crosshead speed of $50 \mathrm{~mm} / \mathrm{min}$ using Lloyd Instruments LRX Materials Testing Machine (Lloyd Instruments Ltd., Hampshire, UK) equipped with a $5000 \mathrm{~N}$ load cell. Hardness (N) (first bite compression), cohesiveness, and chewiness $(\mathrm{N})$ were measured. TPA values for each sample were averaged from six measurements.

\subsection{Lipid Oxidation}

Lipid oxidation in meat was assessed by 2-thiobarbituric reactive substances (TBARS) procedure as reported by Sorensen and Jorgensen [12] with modifications. For each sample, duplicate $(5 \mathrm{~g})$ from each sample were finely chopped and homogenised in $12.5 \mathrm{~mL}$ of chilled $\left(4^{\circ} \mathrm{C}\right)$ trichloroacetic acid (TCA) solution $(20 \%$ TCA $(w / v)$ in $2 \mathrm{M}$ phosphoric acid) at 12,000 rpm for 1.5 min using a Polytron PT 10-35 GT homogeniser (Thermo Fisher Scientific, VIC, Australia). The homogenate was then centrifuged at $1800 \times g$ using a Rotina 380R Hettich Centrifuge (LabGear, South Melbourne, VIC, Australia) for 10 min at $4{ }^{\circ} \mathrm{C}$. The supernatant was filtered using Whatman filter paper no. 1. Equal volumes of the filtrate and $5 \mu \mathrm{M}$ 2-thiobarbituric acid (TBA) were mixed and incubated in a test tube at $95^{\circ} \mathrm{C}$ for $60 \mathrm{~min}$. Following incubation, the tube was placed on ice for $15 \mathrm{~min}$. Absorbance at $532 \mathrm{~nm}$ was measured for duplicate aliquots from each tube using a Multiskan spectrophotometer (Thermo Fisher Scientific, Scoresby, VIC, Australia). Malondialdehyde (MDA) was quantified against a standard calibration curve with 1,1,3,3-tetraethoxypropane (TEP). Results were expressed as $\mathrm{mg} \mathrm{MDA} \cdot \mathrm{kg}^{-1}$ meat.

\subsection{Total Carbonyl Content}

Carbonyl content of the meat samples was determined according to Lund et al. [13] with modifications. Briefly, $1 \mathrm{~g}$ of meat samples were homogenised for 1 min at 15,000 rpm in $15 \mathrm{~mL}$ of homogenisation buffer $\left(2.0 \mathrm{mM} \mathrm{Na}_{4} \mathrm{P}_{2} \mathrm{O}_{7}, 10 \mathrm{mM}\right.$ Tris-maleate, $2 \mathrm{mM}$ EGTA, $100 \mathrm{mM} \mathrm{KCl}, \mathrm{pH}$ 7.4) using a Polytron PT 10-35GT homogeniser (Thermo Fisher Scientific, VIC, Australia). Two equal aliquots $(0.5 \mathrm{~mL})$ from the homogenate were washed with a $\mathrm{HCl}$ :acetone $(3: 100 \mathrm{v} / \mathrm{v})$ solution three times followed by washing with 10\% $(w / v)$ TCA twice. Out of the two identical samples, (i) $0.5 \mathrm{~mL}$ of DNPH dissolved in $2 \mathrm{M} \mathrm{HCl}$ was added to the first sample for carbonyl derivatisation and (ii) $0.5 \mathrm{~mL}$ of $2 \mathrm{M} \mathrm{HCl}$ was added to the other sample for protein concentration determination. Absorbance of the samples were measured at $280 \mathrm{~nm}$ to determine protein concentration against a standard curve with BSA (Sigma-Aldrich, Castle Hill, NSW, Australia); and, at $370 \mathrm{~nm}$ to determine total carbonyl content. Carbonyl concentration was determined by using the absorption coefficient at $370 \mathrm{~nm}$ for the hydrazones formed $\left(22,000 \mathrm{M}^{-1} \cdot \mathrm{cm}^{-1}\right)$ against the protein concentration and expressed as $\mathrm{nmol} \cdot \mathrm{mg}^{-1}$ protein.

\subsection{Free Thiol Content}

To determine the loss of thiol (sulfhydryl) groups, the 5,5'-Dithiobis (2-nitrobenzoic acid) (DTNB) method was used as described by Lund et al. [13]. Duplicates (2 g) of each sample were homogenised at 16,000 rpm in $40 \mathrm{~mL}$ of $5 \%(w / v)$ sodium dodecyl sulfate (SDS) in 0.1 M Tris buffer (pH 8) using a Polytron PT 10-35 GT homogeniser (Thermo Fisher Scientific, Scoresby, VIC, Australia). The homogenates were incubated at $95^{\circ} \mathrm{C}$ for one hour in covered test tubes. The samples were cooled and centrifuges for $20 \mathrm{~min}$ at $1200 \times g$ using a Rotina 380R Hettich centrifuge (LabGear, VIC, Australia). The supernatants were filtered using Whatman filter paper no 1 and the protein concentration of filtrates was determined 
at $280 \mathrm{~nm}$ using a standard curve with bovine serum albumin (BSA) (Sigma-Aldrich, Castle Hill, NSW, Australia). The samples were diluted to a protein concentration of $1.5 \mathrm{mg} \cdot \mathrm{mL}^{-1}$ using the SDS homogenisation buffer. The diluted samples were used to determine thiol group concentration by adding $2 \mathrm{~mL}$ of $0.1 \mathrm{M}$ Tris buffer $(\mathrm{pH} 8)$ and $0.5 \mathrm{~mL}$ DTNB to $0.5 \mathrm{~mL}$ of sample. Samples were incubated for $30 \mathrm{~min}$ in the dark and absorbance at $412 \mathrm{~nm}$ was measured using a Multiskan spectrophotometer (Thermo Fisher Scientific, VIC, Australia). The concentration of thiol groups was analysed against a standard curve of L-cysteine prepared in 5\% $(w / v)$ SDS in $0.1 \mathrm{M}$ Tris buffer $(\mathrm{pH} 8)$. Total thiol content was calculated and expressed as $\mathrm{nmol} \cdot \mathrm{mg}^{-1}$ protein.

\subsection{Statistical Analysis}

Data were analysed using restricted maximum likelihood (REML) with GenStat 16th Edition (VSN International, Hemel Hempstead, UK). For pH before packaging, breed (Composite and Merino), feed type (SPD, SCF and SCM), and muscles (Semimembranosus and Vastus lateralis) were fitted as fixed effects. Pen and carcass number (all nested within, i.e., pen/carcass number) were fitted as random effects. For all other quality traits, breed (Composite and Merino), feed type (SPD, SCF and SCM), packaging method (HioxMAP, TrigasMAP and VSP) were fitted as fixed effects. Pen and carcass number (all nested within) were fitted as random effects. Separate analyses were conducted for each muscle type (Semimembranosus and Vastus lateralis). $p<0.05$ was used as the level for significant differences.

\section{Results}

\section{1. $\mathrm{pH}$ and Colour}

Figure 1 shows that the $\mathrm{pH}$ of meat prior to packaging significantly differed between the Composite and Merino sheep $(p=0.004)$ and between the Semimembranosus and Vastus lateralis muscles $(p<0.001)$. While the $\mathrm{pH}$ of Vastus lateralis was higher compared to Semimembranosus for both breeds, the difference was more substantial in meat from Merino compared to Composite sheep. There was no significant effect of feed $(p=0.7)$ on the $\mathrm{pH}$.

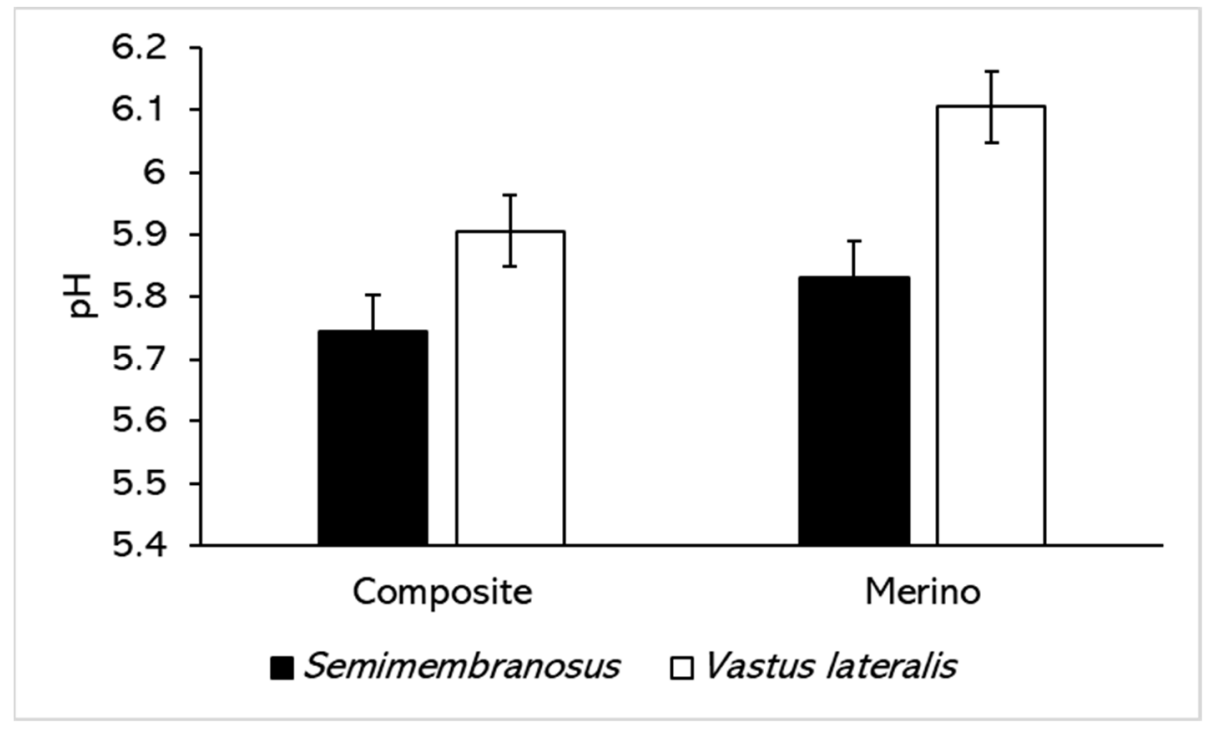

Figure 1. The $\mathrm{pH}$ of Semimembranosus and Vastus lateralis from Composite and Merino sheep before retail packaging. Values are predicted means \pm standard error of differences (SED). $p$ (breed $\times$ muscle) is 0.096 .

Using the CIE L*, $a^{*}$, and $b^{*}$-values, the colour stability of lamb was evaluated (Table 1). Breed had differential effects on the lightness $\left(\mathrm{L}^{*}\right)$ of Semimembranosus and Vastus lateralis muscles. Compared to Composite, Merino had a lower $L^{*}$ value for Semimembranosus, yet a higher $L^{*}$ value for Vastus lateralis. A significant effect of breed on $a^{*}, b^{*}$, and hue were 
also observed for Vastus lateralis, but not Semimembranosus. The finishing feed had no effect on any of the colour parameters. The packaging method had a greater influence on all colour parameters ( $p<0.001$ for all) compared to breed and feed effects. While there were small differences between HioxMAP and TrigasMAP, most colour parameters significantly differed between VSP and HioxMAP or between VSP and TrigasMAP for both muscles. Interestingly, when comparing VSP and HioxMAP, hue differed in Semimembranosus, but not Vastus lateralis. Together, these results show that the choice of packaging methods had a greater influence on the colour stability of sheep meat, compared to breed and feed, and the extent to which of HioxMAP negatively impacts meat colour was muscle dependent. A visual illustration of Vastus lateralis in the three packaging methods is presented in Figure 2.
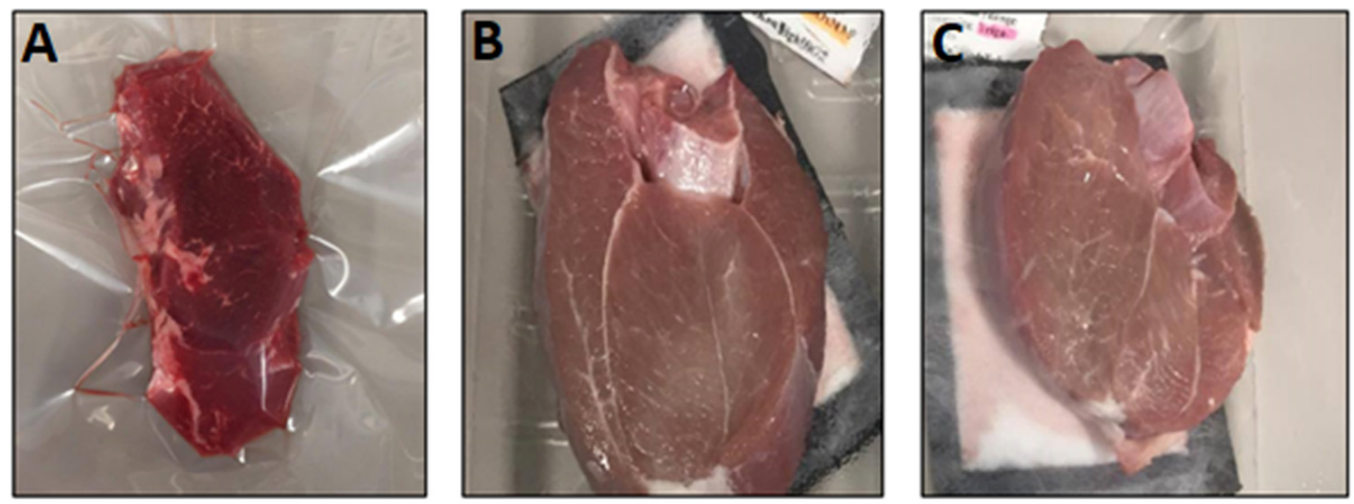

Figure 2. Visual comparison of Vastus lateralis from a Composite sheep finished on standard pelleted diet with grain and hay and packed in (A) vacuum skin packaging; (B) HioxMAP; or (C) TrigasMAP for 10 days at $4{ }^{\circ} \mathrm{C}$.

\subsection{Water Holding Capacity}

Water holding capacity was measured as purge and cooking losses (Table 2). While the three supply chain factors (breed, feed, and packaging method) appear to influence purge loss to a similar extent, only packaging method had a significant effect $(p<0.001)$ on purge loss. It is worth noting that purge loss of Semimembranosus in TrigasMAP (5.7\% \pm 0.3 SED) was similar to VSP $(5.7 \% \pm 0.3$ SED) and lower than HioxMAP $(6.8 \% \pm 0.3$ SED). There was no difference in purge loss of Vastus lateralis in HioxMAP and TrigasMAP, indicating differences between the two muscles in their response to water holding capacity. A significant interaction between breed and packaging method was also observed for purge loss (Figure 3). While the purge loss did not differ across the three packaging methods for composite sheep Semimembranosus and Vastus lateralis, TrigasMAP reduced the purge loss in Merino Semimembranosus compared to HioxMAP (Figure 3A). This reduction in purge loss by TrigasMAP was not observed for Vastus lateralis (Figure 3B). Packaging method had a significant effect on purge loss of Semimembranosus and Vastus lateralis from Merino, but not those from Composite sheep.

Merino Semimembranosus had a lower cooking loss compared to the same muscle type from Composite sheep (Table 2). Finishing feed did not affect cooking loss for either Semimembranosus or Vastus lateralis. The difference in cooking loss between the three packaging methods were significant with the lowest cooking loss in TrigasMAP (30.9\% \pm 0.5 SED), followed by HioxMAP (32.2\% \pm 0.5 SED) and VSP (35.1\% \pm 0.5 SED). No significant interactions were observed for cooking loss. 
Table 1. Effect of breed, feed and packaging method on the CIELab colour parameters of sheep Semimembranosus and Vastus lateralis after 10-day retail display

\begin{tabular}{|c|c|c|c|c|c|c|c|c|c|c|c|}
\hline \multirow{2}{*}{ Effect } & \multirow{2}{*}{ Treatment } & \multicolumn{2}{|c|}{$\mathrm{L}^{*}$ (Lightness) } & \multicolumn{2}{|c|}{$\mathrm{a}^{*}$ (Redness) } & \multicolumn{2}{|c|}{$b^{*}$ (Yellowness) } & \multicolumn{2}{|c|}{$h^{*}$ (Hue Angle) } & \multicolumn{2}{|c|}{$\mathrm{C}^{*}$ (Chroma) } \\
\hline & & Coeff & $p$-Value & Coeff & $p$-Value & Coeff & $p$-Value & Coeff & $p$-Value & Coeff & $p$-Value \\
\hline & $\begin{array}{l}\text { Semimembranosus } \\
\text { Constant }^{1}\end{array}$ & $37.5 \pm 1.37$ & & $20.41 \pm 1.02$ & & $19.63 \pm 0.98$ & & $43.67 \pm 2.33$ & & $28.55 \pm 1.16$ & \\
\hline \multirow{2}{*}{ Feed } & $\mathrm{SCF}^{2}$ & $2.7 \pm 2.44$ & 0.194 & $-1.89 \pm 1.82$ & 0.418 & $-1.70 \pm 1.78$ & 0.712 & $1.86 \pm 4.27$ & 0.671 & $-2.93 \pm 2.12$ & 0.29 \\
\hline & $\mathrm{SCM}^{3}$ & $-2.3 \pm 2.44$ & 0.194 & $0.46 \pm 1.82$ & 0.418 & $1.01 \pm 1.78$ & 0.712 & $2.14 \pm 4.27$ & 0.671 & $0.68 \pm 2.12$ & 0.29 \\
\hline \multirow{3}{*}{ Packaging } & HioxMAP ${ }^{4}$ & $9.91 \pm 1.57$ & $<0.001$ & $-11.71 \pm 1.48$ & $<0.001$ & $-6.46 \pm 1.24$ & $<0.001$ & $13.3 \pm 3.24$ & $<0.001$ & $-12.64 \pm 1.63$ & $<0.001$ \\
\hline & TrigasMAP 5 & $9.72 \pm 1.57$ & $<0.001$ & $-11.39 \pm 1.48$ & $<0.001$ & $-7.66 \pm 1.24$ & $<0.001$ & $9.6 \pm 3.24$ & $<0.001$ & $-13.44 \pm 1.63$ & $<0.001$ \\
\hline & $\begin{array}{c}\text { Vastus lateralis } \\
\text { Constant }{ }^{6}\end{array}$ & $38.99 \pm 1.52$ & & $19.33 \pm 1.05$ & & $18.37 \pm 0.84$ & & $42.96 \pm 2.5$ & & $26.74 \pm 1.07$ & \\
\hline Breed & Merino & $0.62 \pm 2.48$ & $<0.001$ & $-2.94 \pm 1.74$ & 0.005 & $-5.18 \pm 1.37$ & 0.043 & $-2.75 \pm 4.11$ & 0.003 & $-5.33 \pm 1.75$ & 0.08 \\
\hline \multirow{2}{*}{ Feed } & $\mathrm{SCF}^{2}$ & $1.38 \pm 2.49$ & 0.63 & $-0.89 \pm 1.72$ & 0.104 & $-0.22 \pm 1.39$ & 0.174 & $1.52 \pm 4.05$ & 0.452 & $-0.78 \pm 1.76$ & 0.053 \\
\hline & $\mathrm{SCM}^{3}$ & $1.58 \pm 2.49$ & 0.63 & $-0.35 \pm 1.72$ & 0.104 & $2.07 \pm 1.39$ & 0.174 & $4.19 \pm 4.05$ & 0.452 & $1.21 \pm 1.76$ & 0.053 \\
\hline \multirow{2}{*}{ Packaging } & HioxMAP ${ }^{4}$ & $9.74 \pm 1.48$ & $<0.001$ & $-6.88 \pm 0.98$ & $<0.001$ & $-5.99 \pm 0.90$ & $<0.001$ & $2.9 \pm 2.14$ & $<0.001$ & $-9.1 \pm 1.09$ & $<0.001$ \\
\hline & TrigasMAP 5 & $10.45 \pm 1.48$ & $<0.001$ & $-9.25 \pm 0.98$ & $<0.001$ & $-6.59 \pm 0.90$ & $<0.001$ & $6.72 \pm 2.14$ & $<0.001$ & $-11.19 \pm 1.09$ & $<0.001$ \\
\hline
\end{tabular}

Coefficients \pm standard error of differences (Coeff \pm SED) and level of significance ( $p$-values) are presented. ${ }^{1}$ For Semimembranosus from a Composite lamb, finished on a standard pelleted diet containing grain and cereal hay, and retail displayed in vacuum skin packaging for 10 days. ${ }^{2} \mathrm{SCF}=$ standard pelleted diet containing $15 \%$ camelina forage hay. ${ }^{3} \mathrm{SCM}=$ standard pelleted diet containing $8 \%$ camelina meal $(\mathrm{SCM}) .{ }^{4}$ HioxMAP $=$ high-oxygen modified atmosphere packaging with $80 \% \mathrm{O}_{2}$ and $20 \% \mathrm{CO}_{2} ;{ }^{5}$ TrigasMAP $=$ trigas modified atmosphere packaging with $50 \% \mathrm{O}_{2}, 30 \% \mathrm{~N}_{2}$ and $20 \% \mathrm{CO}_{2} ;{ }^{6}$ For Vastus lateralis from a Composite sheep, fed with standard pelleted diet containing grain and cereal hay, and packaged in vacuum skin packaging. 
Table 2. Effect of breed, feed and packaging method on water holding capacity and texture measurements of sheep Semimembranosus (topside) and Vastus lateralis (knuckle).

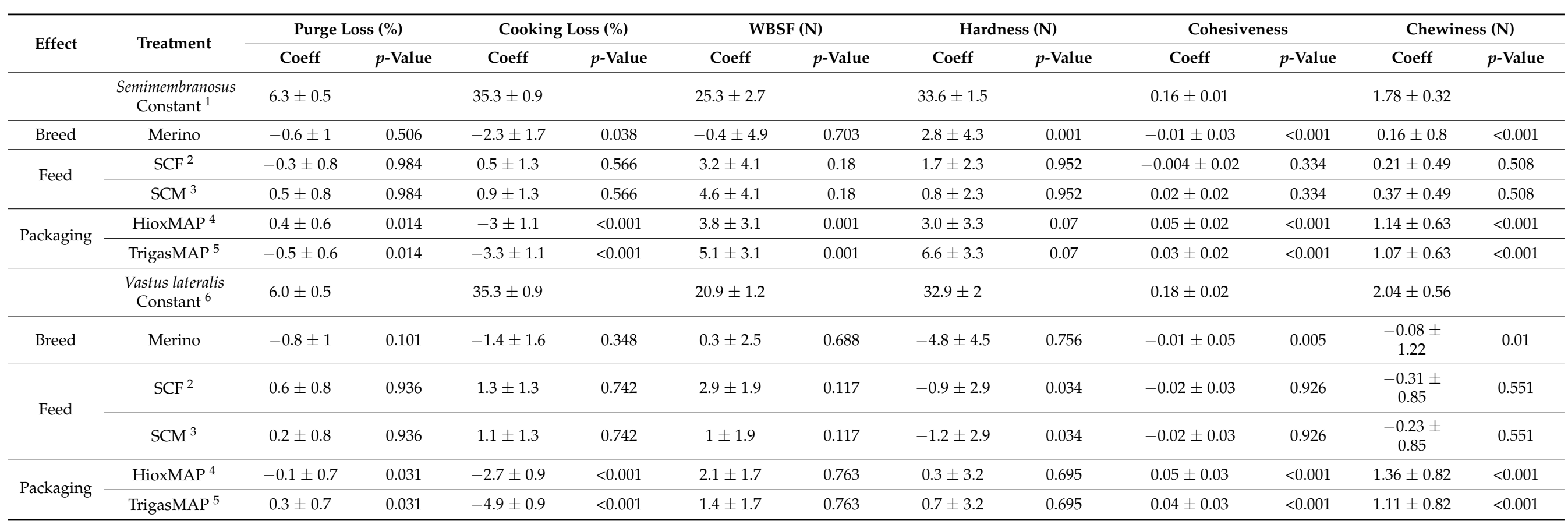

Coefficients \pm standard error of differences (Coeff \pm SED) and level of significance ( $p$-values) are presented. ${ }^{1}$ For Semimembranosus from a Composite lamb, finished on a standard pelleted diet containing grain and cereal hay, and retail displayed in vacuum skin packaging for 10 days. ${ }^{2} \mathrm{SCF}=$ standard pelleted diet containing $15 \%$ camelina forage hay. ${ }^{3} \mathrm{SCM}=$ standard pelleted diet containing $8 \%$ camelina meal $(\mathrm{SCM}) .{ }^{4}$ HioxMAP = high-oxygen modified atmosphere packaging with $80 \% \mathrm{O}_{2}$ and $20 \% \mathrm{CO}{ }_{2} ;{ }^{5}$ TrigasMAP $=$ trigas modified atmosphere packaging with $50 \% \mathrm{O}_{2}, 30 \% \mathrm{~N}_{2}$ and $20 \% \mathrm{CO}_{2} ;{ }^{6}$ For Vastus lateralis from a Composite sheep, fed with standard pelleted diet containing grain and cereal hay, and packaged in vacuum skin packaging. 
A

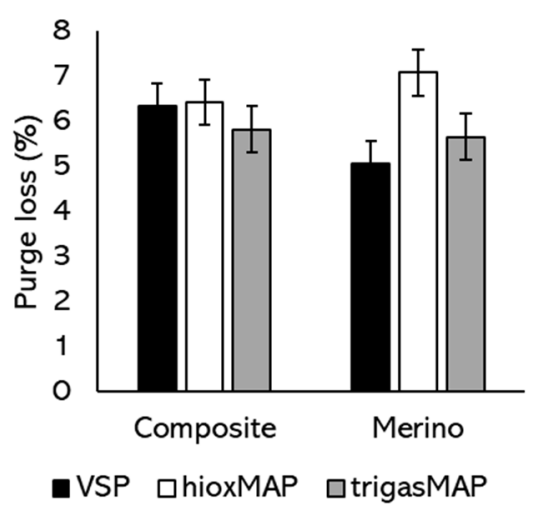

B

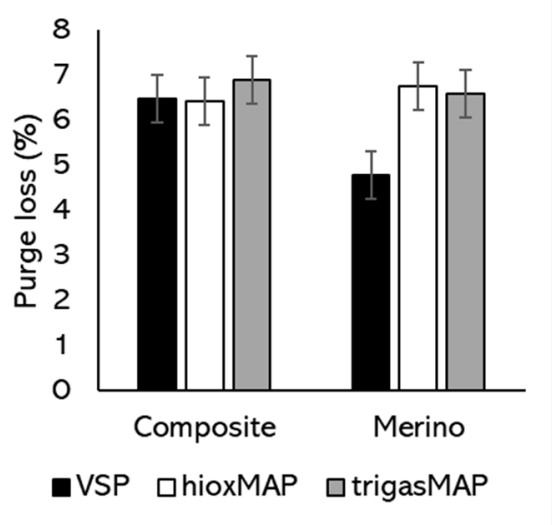

Figure 3. Purge loss of (A) Semimembranosus and (B) Vastus lateralis from two sheep breeds (Composite or Merino) in three retail packaging methods (VSP = vacuum skin packaging; HioxMAP = high-oxygen modified atmosphere packaging with $80 \% \mathrm{O}_{2}$ and $20 \% \mathrm{CO}_{2}$; or TrigasMAP = trigas modified atmosphere packaging with $50 \% \mathrm{O}_{2}, 30 \% \mathrm{~N}_{2}$ and $20 \% \mathrm{CO}_{2}$ ). Values are predicted means \pm standard error of differences (SED). $p$ (breed $\times$ packaging method) values are 0.014 for Semimembranosus (A) and 0.015 for Vastus lateralis (B).

\subsection{WBSF and Texture Profile Analysis}

Breed or finishing feed had no effect on WBSF for either of the two muscles (Table 2). Differences in WBSF between the three packaging methods were only found for Semimembranosus, which were tougher in HioxMAP and TrigasMAP, compared to VSP. No significant interactions were observed for WBSF in either muscle types.

The effect of the three supply chain factors on Texture Profile Analysis hardness differed between the two muscles (Table 2). Within the Semimembranosus samples, hardness was affected by breed only, with Semimembranosus from Merino having a higher hardness value compared to Semimembranosus from Composite sheep. The hardness of Vastus lateralis was only affected by finishing feed, with SCM having a lower hardness value than that of SPD and SCF. Cohesiveness and chewiness were affected by breed and packaging method in both muscle types. Cohesiveness and chewiness were lower in VSP compared to HioxMAP and TrigasMAP for both muscle type, suggesting a softer texture in a low oxygen packaging environment. No significant interactions were observed for hardness, cohesiveness, and chewiness in either muscle types.

\subsection{Lipid Oxidation}

Lipid oxidation in meat was assessed using TBARS assay and the levels were expressed as mg MDA $/ \mathrm{kg}$ of meat. Breed did not affect lipid oxidation in either of the two muscle types (Table 3). However, supplementation of feed with either camelina forage or camelina meal led to a reduction in TBARS values compared to the standard pelleted diet containing cereal hay and grains. Packaging type not only had a significant effect but also to a greater extent (substantially higher coefficients) than feed on TBARS values. TrigasMAP was able to reduce lipid oxidation compared to HioxMAP for Semimembranosus, but not Vastus lateralis. There was also a significant interaction between finishing feed and packaging method for the Semimembranosus samples. Figure 4 shows that the TBARS value of meat in HioxMAP were substantially greater in the control diet (SPD) compared to the two camelina supplemented diets (SCF and SCM), especially for Semimembranosus. These results further emphasise the need for sheep meat to be packaged in a lower oxygen environment when sheep feed is not supplemented with antioxidants. 
Table 3. Effect of breed, feed and packaging method on lipid and protein oxidation measurements of sheep Semimembranosus (topside) and Vastus lateralis (knuckle).

\begin{tabular}{|c|c|c|c|c|c|c|c|}
\hline \multirow[t]{2}{*}{ Effect } & \multirow[t]{2}{*}{ Treatment } & \multicolumn{2}{|c|}{ TBARS (mg MDA $\cdot \mathrm{kg}^{-1}$ Meat) } & \multicolumn{2}{|c|}{ Total Carbonyl (nmol· $\mathrm{mg}^{-1}$ Protein) } & \multicolumn{2}{|c|}{$\begin{array}{l}\text { Free Thiol Content } \\
\left(\mathrm{nmol} \cdot \mathrm{mg}^{-1} \text { Protein) }\right.\end{array}$} \\
\hline & & Coeff & $p$-Value & Coeff & $p$-Value & Coeff & $p$-Value \\
\hline & $\begin{array}{l}\text { Semimembranosus } \\
\text { Constant }{ }^{1}\end{array}$ & $0.51 \pm 0.33$ & & $1.52 \pm 0.58$ & & $53.48 \pm 3.14$ & \\
\hline Breed & Merino & $-0.13 \pm 0.46$ & 0.323 & $-0.11 \pm 0.77$ & 0.781 & $-14.87 \pm 6.85$ & 0.661 \\
\hline \multirow{2}{*}{ Feed } & $\mathrm{SCF}^{2}$ & $-0.4 \pm 0.47$ & 0.034 & $-0.66 \pm 0.81$ & 0.395 & $0.85 \pm 5.02$ & 0.37 \\
\hline & $\mathrm{SCM}^{3}$ & $-0.28 \pm 0.47$ & 0.034 & $-0.50 \pm 0.81$ & 0.395 & $0.02 \pm 5.02$ & 0.37 \\
\hline \multirow{3}{*}{ Packaging } & HioxMAP $^{4}$ & $4.05 \pm 0.45$ & $<0.001$ & $1.75 \pm 0.58$ & $<0.001$ & $-10.62 \pm 2.52$ & $<0.001$ \\
\hline & TrigasMAP $^{5}$ & $1.80 \pm 0.45$ & $<0.001$ & $1.74 \pm 0.58$ & $<0.001$ & $-8.92 \pm 2.52$ & $<0.001$ \\
\hline & $\begin{array}{l}\text { Vastus lateralis } \\
\text { Constant }\end{array}$ & $0.29 \pm 0.36$ & & $1.2 \pm 0.29$ & & $54.62 \pm 3.15$ & \\
\hline Breed & Merino & $0.14 \pm 0.50$ & 0.716 & $0.28 \pm 0.41$ & 0.404 & $-13.21 \pm 6.51$ & 0.424 \\
\hline \multirow{2}{*}{ Feed } & $\mathrm{SCF}^{2}$ & $-0.23 \pm 0.54$ & 0.06 & $-0.36 \pm 0.42$ & 0.162 & $0.36 \pm 5$ & 0.382 \\
\hline & $\mathrm{SCM}^{3}$ & $-0.11 \pm 0.54$ & 0.06 & $-0.23 \pm 0.41$ & 0.162 & $-1.62 \pm 5$ & 0.382 \\
\hline \multirow{2}{*}{ Packaging } & HioxMAP ${ }^{4}$ & $2.59 \pm 0.41$ & $<0.001$ & $2.06 \pm 0.39$ & $<0.001$ & $-10.29 \pm 2.43$ & $<0.001$ \\
\hline & TrigasMAP 5 & $2.67 \pm 0.41$ & $<0.001$ & $1.96 \pm 0.39$ & $<0.001$ & $-8.22 \pm 2.43$ & $<0.001$ \\
\hline
\end{tabular}

Coefficients \pm standard error of differences (Coeff \pm SED) and level of significance ( $p$-values) are presented. ${ }^{1}$ For Semimembranosus from a Composite lamb, finished on a standard pelleted diet containing grain and cereal hay, and retail displayed in vacuum skin packaging for 10 days. ${ }^{2} \mathrm{SCF}=$ standard pelleted diet containing $15 \%$ camelina forage hay. ${ }^{3} \mathrm{SCM}=$ standard pelleted diet containing $8 \%$ camelina meal (SCM). ${ }^{4}$ HioxMAP $=$ high-oxygen modified atmosphere packaging with $80 \% \mathrm{O}_{2}$ and $20 \% \mathrm{CO}_{2} ;{ }^{5}$ TrigasMAP $=$ trigas modified atmosphere packaging with $50 \% \mathrm{O}_{2}, 30 \% \mathrm{~N}_{2}$ and $20 \% \mathrm{CO}_{2} ;{ }^{6}$ For Vastus lateralis from a Composite sheep, fed with standard pelleted diet containing grain and cereal hay, and packaged in vacuum skin packaging.
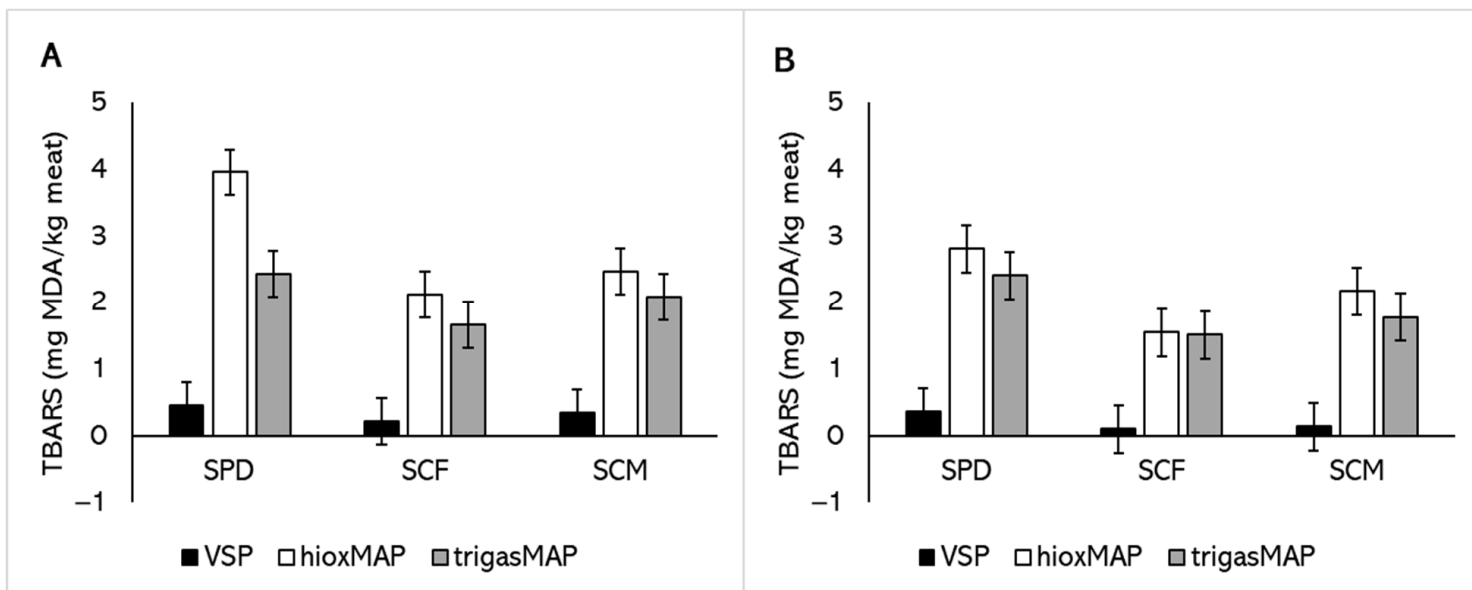

Figure 4. Thiobarbituric acid reactive substances (TBARS) values of (A) Semimembranosus and (B) Vastus lateralis from sheep finished on three diets $(\mathrm{SPD}=$ standard pelleted diet containing grain and cereal hay; SCF = pelleted mixture diet containing 15\% camelina forage hay; or SCM = pelleted mixture diet containing $8 \%$ camelina meal) and retail displayed in three packaging methods (VSP = vacuum skin packaging; HioxMAP = high-oxygen modified atmosphere packaging with $80 \% \mathrm{O}_{2}$ and $20 \% \mathrm{CO}_{2}$; or TrigasMAP = trigas modified atmosphere packaging with $50 \% \mathrm{O}_{2}, 30 \% \mathrm{~N}_{2}$ and $20 \% \mathrm{CO}_{2}$ ). Values are predicted means \pm standard error of differences (SED). $p$ (feed $\times$ packaging method) values are 0.011 for Semimembranosus (A) and 0.243 for Vastus lateralis (B).

\subsection{Protein Oxidation}

There were no differences between breed and finishing feed treatments on total carbonyl and free thiol content in either Semimembranosus or Vastus lateralis (Table 3). On the 
other hand, protein oxidation significantly differed between the three packaging methods in both muscle types. Total carbonyl was significantly lower in VSP compared to HioxMAP and TrigasMAP. There was a small but significant difference between total carbonyl of HioxMAP and TrigasMAP with TrigasMAP inducing a lower carbonyl generation. The free thiol content values were significantly lower in VSP compared to either HioxMAP or TrigasMAP for both muscle types, suggesting that minimising protein oxidation in sheep meat can be achieved by the use of oxygen at a level below $50 \%$. Within SPD treatment, Merino Semimembranosus or Vastus lateralis had lower free thiol contents compared to equivalent muscles from Composite sheep, indicating the importance of cameline in sheep finishing diets for Merino sheep to reduce protein oxidation. This difference was not observed for total carbonyl.

\section{Discussion}

\subsection{Colour and $p H$}

Differences in Instrumental CIELab parameters due to breed was more apparent in Vastus lateralis compared to Semimembranosus. Merino Vastus lateralis had higher $\mathrm{L}^{*}$, and lower $a^{*}, b^{*}$, hue, and chroma than the same muscle from Composite sheep. These results suggest that the meat from Merino sheep was less colour stable, which coincided with a substantially higher $\mathrm{pH}$ compared to meat from Composite sheep. This agrees with a previous study which found the fastest drop in oxy-/met-myoglobin ratio in meat from Merino, compared to other crossbreeds [14]. The lower colour stability in Merino sheep meat was also reported in other studies $[9,10]$. Furthermore, significant differences in fatty acid composition and vitamin E concentration were found in the Longissimus of Merino and crossbred sheep $[7,10]$. These differences are likely to result in variation in the oxidation of myoglobin, thus affecting the colour stability of meat.

Breed and $\mathrm{pH}$ have been shown to be among the most important predictors in sheep meat colour stability. Meat from Merino often has a different ultimate $\mathrm{pH}$ to meat from crossbreed sheep $[10,14]$. A study on lamb from the Australian Cooperative Research Centre for Sheep Industry Innovation showed that Merino Longissimus with a higher $\mathrm{pH}$ had the least colour stability in overwrap [14]. The link between breed, ultimate $\mathrm{pH}$, and colour stability is complex. Meat $\mathrm{pH}$ has been linked to myoglobin autooxidation, changes in enzymatic activities, iron molecule oxidation, and light scattering, all of which affect the appearance of the meat [15]. It is worth noting that most studies on sheep meat have focused mainly on the Longissimus, which is known to differ from Semimembranosus and Vastus lateralis in muscle fibre type, contributing to differences in colour [15].

Myoglobin oxidation and oxygenation status is affected by the level of oxygen during retail packaging. This study shows that the storage of lamb under high $(80 \%)$ and moderate (50\%) oxygen environments for 10 days significantly reduces the colour stability of both Semimembranosus and Vastus lateralis, when compared to lamb stored in VSP. The significant decrease in $\mathrm{L}^{*}, \mathrm{a}^{*}, \mathrm{~b}^{*}$, hue and chroma in HioxMAP, compared to VSP, are consistent with the results of previous studies [3,16,17]. Lower chroma and higher hue values are undesirable in red meat as it represents paler and duller meat [18]. The colour results from TrigasMAP in the present study suggest that after 10 days of storage, TrigasMAP does not offer enhanced colour stability, similar to results of Resconi et al. [16] in which beef were displayed in different $\mathrm{O}_{2}$ levels for up to 8 days. However, it is possible that meat in TrigasMAP with a shorter retail display time may have better colour than in HioxMAP. Zakrys et al. [19] suggested that $50 \% \mathrm{O}_{2} ; 30 \% \mathrm{~N}_{2} ; 20 \% \mathrm{CO}_{2}$ may provide opportunity for improved shelf life by enhancing the $a^{*}$ value of beef, compared to HioxMAP after a 3-day storage. Meat surface colour has been shown to deteriorate after three days of storage in HioxMAP [20]. This was attributed to the reduction of metmyoglobin reducing activity during prolonged storage, thereby favouring the oxidative process of oxymyoglobin to metmyoglobin. The study of Khliji et al. [21] indicated that consumers discriminate against red meat with $\mathrm{a}^{*}$ values below 14.5. The $\mathrm{a}^{*}$ values for both muscles in HioxMAP and TrigasMAP were well below this threshold for both muscles in this study. Thus, retail 
displaying of sheep meat in HioxMAP or TrigasMAP for 10 days is not recommended for colour enhancement.

\subsection{Water Holding Capacity and Texture}

Contradictory results have been reported for the purge loss of meat in different packaging treatments, while others reported an increase in the purge of meat under vacuum [22]. Taylor et al. [17] showed that the weight loss of vacuum-packed beef and pork was less than MAP $\left(75 \% \mathrm{O}_{2} / 25 \% \mathrm{CO}_{2}\right)$-packed samples after storage. Similar results were reported in other studies [23,24]. However, it was suggested in a review by McMillin [25] that the purge loss of meat displayed under vacuum packaging is higher than MAP, partly attributed to the negative pressure. In the current study, the two muscles responded differently to the effect of packaging. HioxMAP led to a higher purge loss for Semimembranosus but lower purge loss for Vastus lateralis compared to VSP, emphasising that future purge loss investigations should consider muscle differences.

Unlike purge loss, similar cooking losses were observed for both muscle types with a higher cooking loss found for both HioxMAP and TrigasMAP compared to VSP, in agreement with previous studies [26]. On the other hand, cooking loss due to breed differences appear to be muscle-specific, with Semimembranosus from Merino having a lower cooking loss compared to the same muscle from Composite. While the underlying mechanisms of water holding capacity remains an ongoing research area, previous studies showed that variations in muscle fibre type and connective tissue composition play a role in cooking loss differences [27-29].

Packaging appeared to affect the two muscles differently. WBSF of Semimembranosus in HioxMAP and TrigasMAP were higher than VSP. Similar results have been reported for beef topside and beef round, where the beef topside is a more likely response to ageing than beef round muscle after storage [30]. Numerous studies have shown the negative effect of HioxMAP on sheep meat eating quality. Frank et al. [1] showed a significantly lower sensory tenderness of lamb in HioxMAP compared to VSP. Similar results on various texture measurements were also found for meat from other species [11,13,31]. Previous studies found while the WBSF of beef Longissimus did not differ between oxygen levels from $40-80 \%$, sensory panellists preferred beef in lower $\mathrm{O}_{2}$ environments $40-50 \%[19,32,33]$. Furthermore, various studies have established that the toughening of meat in HioxMAP is caused by increased protein oxidation resulting in more disulfide bond formation between actomyosin complexes, less degradation of structural proteins, e.g., desmin and troponin $\mathrm{T}$, and deactivation of calpain [13,32,34-36]. It is worth noting that the exact mechanisms appeared to be muscle- and species-specific $[2,3,34]$. Our results on texture are consistent with the protein oxidation results, which showed that significant differences were only found when VSP was compared to HioxMAP and TrigasMAP. Together, these results indicate VSP is the preferred packaging method for lamb regardless of breed and finishing feed treatments.

\subsection{Lipid Oxidation}

Lipid oxidation is a key quality determinant in meat, as it causes the development of off-flavours and rancidity in meat. Free radical formation from lipid oxidation has also been linked to increased myoglobin oxidation and thus discolouration [37]. Feeding strategy of livestock can play a significant role in manipulating lipid oxidation of meat. The present study found a reduction of lipid oxidation of Semimembranosus and Vastus lateralis from sheep finished on diets supplemented with camelina forge or camelina meal. These findings compliment previous studies which found significant decreases in TBARS for forage fed animals when compared to grain-fed animals $[5,38,39]$. Lamb muscles finished on diets supplemented with camelina cake has been shown to have a different fatty acid composition compared to those on the standard pelleted diet without camelina supplementation [40]. Furthermore, we have reported in a separate study that both camelina hay- and camelia meal-supplemented diets reduced $(p<0.001)$ arachidonic acid concentration of Longissimus 
from these animals compared with the SPD diet [7]. In addition, the SCM diet significantly increased alpha linolenic acid (ALA) concentration of the Longissimus compared to SPD and $\mathrm{SCF}$, resulting in an increase in total omega- 3 concentration and the decrease in the ratio of $n-6 / n-3$ in meat [7].

The packaging results in this study show that TrigasMAP is an effective method to reduce lipid oxidation in packaging, regardless of breed and finishing feed treatments, consistent with previous studies on the effect of varying oxygen content on lipid oxidation $[19,34,41]$. Reducing oxygen content in retail packaging is even more important when sheep is not finished on supplemented diet.

Consumers discriminate against the off-flavour of beef when TBARS reaches the $2.28 \mathrm{mg} \mathrm{MDA} / \mathrm{kg}$ meat threshold [42]. While similar investigations are needed for sheep meat, the present findings suggest that retail display of sheep meat in HioxMAP for 10 days leads to unacceptable flavour regardless of breed, feed or muscles. Supplementation of finishing feeds with camelina forage and TrigasMAP offers the potential to reduce TBARS values to below this threshold, thus reducing the economic loss for the industry. It should be noted that VSP provided consistently minimal lipid oxidation regardless of breed, feed or muscle treatments.

\subsection{Protein Oxidation}

Protein oxidation during retail display has been shown to lead to changes in protein aggregation and degradation, with implication for meat tenderisation. Carbonyl content substantially increased after 10 days of retail display in both TrigasMAP and HioxMAP (Table 3). Interestingly, TrigasMAP reduced the extent of formation of carbonyl groups compared to HioxMAP. This is similar to that observed in lipid oxidation, and agrees with previous studies [19] which reported increases in carbonyl content with increases in oxygen concentration. This would suggest that reducing the oxygen concentration in the packaging system to $50 \%$ reduced the extent of post-mortem oxidative processes.

Morzel et al. [43], using an $\cdot \mathrm{OH}$ radical generating system from pig Longissimus, showed oxidation induced formation of disulfide bridge and protein polymerisation led to a reduction in proteolysis susceptibility of myofibril proteins. Free thiol groups (sulfhydryl) are susceptible to oxidation; therefore, the quantification is a useful measure to determine the extent of protein oxidation in muscle foods. The present study showed the free thiol content of both Semimembranosus and Vastus lateralis did not differ between breed and finishing feed treatments. However, significant differences were observed between VSP and HioxMAP and TrigasMAP treatments. Bao and Ertbjerg [34] reported no difference in free thiol content between $80 \% \mathrm{O}_{2}$ and $60 \% \mathrm{O}_{2}$ in HioxMAP packaged beef. The underlying mechanisms behind differences in free thiol content between Composite and Merino on SPD is not understood. However, differences in muscle fibre type, lipid content and composition, and antioxidant capacities between breeds are likely to be involved [44].

\section{Conclusions}

By examining the colour, water holding capacity, texture, and oxidative stability of sheep meat from different breeds, finishing feed, and retail packaging methods, this study demonstrated the complexity in how different sheep breeds and muscles respond to variations in finishing feeds and packaging methods. Packaging of sheep meat in low, moderate, or high oxygen environments affected the colour to a greater extent than breed and finishing feeds. However, supplementation of the finishing feed with either camelina forage or camelina meal significantly reduced the lipid oxidation of sheep meat. Understanding how and to which extent supply chain factors affect the quality of sheep meat enables sheep producers and processors to prioritise intervention strategies to ensure optimal quality.

Author Contributions: Conceptualization, E.N.P. and M.H.; methodology, E.N.P. and M.H.; validation, M.H., S.W. and C.K.; formal analysis, M.H.; investigation, S.W. and C.K.; resources, E.N.P. and R.D.W.; data curation, M.H.; writing-original draft preparation, M.H., C.K. and S.W.; writing- 
review and editing, M.H., R.D.W. and E.N.P.; supervision, M.H. and R.D.W.; project administration, E.N.P. and M.H.; funding acquisition, E.N.P. All authors have read and agreed to the published version of the manuscript.

Funding: The funding for the animal feeding experiment was provided by the Victorian Department of Jobs, Precincts and Regions (Agriculture Victoria Research), grant number CMI 105393.

Institutional Review Board Statement: The study was conducted according to the Australian Code of Practice for the Care and Use of Animals for Scientific Purposes, and approved by the Agricultural Research and Extension Animal Ethics Committee of the Department of Jobs, Precincts and Regions (AEC Approval No: 2016-17).

Informed Consent Statement: Not applicable.

Data Availability Statement: The data presented in this study are available on reasonable request.

Acknowledgments: The authors gratefully acknowledge the technical contributions of staff from Hamilton and Bundoora during animal feeding, slaughter, and primal cuts collection. The camelina forage and camelina meal were purchased from Yarrock Pty Ltd., Kaniva, VIC 3419, Australia. Technical and operational support from the Faculty of Veterinary and Agricultural Sciences, The University of Melbourne is also acknowledged for the collection of muscle cuts, biochemical analyses, and meat quality measurements.

Conflicts of Interest: The authors declare no conflict of interest. The funder had no role in the design of the study; in the collection, analyses, or interpretation of data; in the writing of the manuscript, or in the decision to publish the results.

\section{References}

1. Frank, D.C.; Geesink, G.; Alyarenga, T.I.R.C.; Polkinghorne, R.; Stark, J.; Lee, M.; Warner, R. Impact of high oxygen and vacuum retail ready packaging formats on lamb loin and topside eating quality. Meat Sci. 2017, 123, 126-133. [CrossRef] [PubMed]

2. Geesink, G.; Robertson, J.; Ball, A. The effect of retail packaging method on objective and consumer assessment of beef quality traits. Meat Sci. 2015, 104, 85-89. [CrossRef]

3. Kim, Y.H.; Huff-Lonergan, E.; Sebranek, J.G.; Lonergan, S.M. High-oxygen modified atmosphere packaging system induces lipid and myoglobin oxidation and protein polymerization. Meat Sci. 2010, 85, 759-767. [CrossRef] [PubMed]

4. Torngren, M.A.; Darre, M.; Gunvig, A.; Bardenshtein, A. Case studies of packaging and processing solutions to improve meat quality and safety. Meat Sci. 2018, 144, 149-158. [CrossRef] [PubMed]

5. Luciano, G.; Monahan, F.J.; Vasta, V.; Pennisi, P.; Bella, M.; Priolo, A. Lipid and colour stability of meat from lambs fed fresh herbage or concentrate. Meat Sci. 2009, 82, 193-199. [CrossRef] [PubMed]

6. Ponnampalam, E.N.; Dunshea, F.R.; Warner, R.D. Use of lucerne hay in ruminant feeds to improve animal productivity, meat nutritional value and meat preservation under a more variable climate. Meat Sci. 2020, 170, 108235. [CrossRef]

7. Ponnampalam, E.N.; Butler, K.L.; Muir, S.K.; Plozza, T.E.; Kerr, M.G.; Brown, W.G.; Jacobs, J.L.; Knight, M.I. Lipid oxidation and colour stability of lamb and yearling meat (muscle longissimus lumborum) from sheep supplemented with camelina-based diets after short-, medium-, and long-term storage. Antioxidants 2021, 10, 166. [CrossRef]

8. Quezada, N.; Cherian, G. Lipid characterization and antioxidant status of the seeds and meals of Camelina sativa and flax. Eur. J. Lipid. Sci. Technol. 2012, 114, 974-982. [CrossRef]

9. Cloete, J.; Hoffman, L.; Cloete, S. A comparison between slaughter traits and meat quality of various sheep breeds: Wool, dual-purpose and mutton. Meat Sci. 2012, 91, 318-324. [CrossRef] [PubMed]

10. Mortimer, S.I.; van der Werf, J.H.; Jacob, R.H.; Hopkins, D.L.; Pannier, L.; Pearce, K.L.; Gardner, G.E.; Warner, R.D.; Geesink, G.H.; Edwards, J.E.; et al. Genetic parameters for meat quality traits of Australian lamb meat. Meat Sci. 2014, 96, 1016-1024. [CrossRef]

11. Peng, Y.L.; Adhiputra, K.; Padayachee, A.; Channon, H.; Ha, M.; Warner, R.D. High oxygen modified atmosphere packaging negatively influences consumer acceptability traits of pork. Foods 2019, 8, 567. [CrossRef] [PubMed]

12. Sorensen, G.; Jorgensen, S.S. A critical examination of some experimental variables in the 2-thiobarbituric acid (TBA) test for lipid oxidation in meat products. Z. Lebensm. Unters. Forsch. 1996, 202, 205-210. [CrossRef]

13. Lund, M.N.; Lametsch, R.; Hviid, M.S.; Jensen, O.N.; Skibsted, L.H. High-oxygen packaging atmosphere influences protein oxidation and tenderness of porcine longissimus dorsi during chill storage. Meat Sci. 2007, 77, 295-303. [CrossRef]

14. Jacob, R.H.; D'Antuono, M.F.; Gilmour, A.R.; Warner, R.D. Phenotypic characterisation of colour stability of lamb meat. Meat Sci. 2014, 96, 1040-1048. [CrossRef] [PubMed]

15. Bekhit, A.; Morton, J.D.; Bhat, Z.F.; Kong, L. Meat color: Factors affecting color stability. In Encyclopedia of Food Chemistry; Varelis, P., Melton, L., Shahidi, F., Eds.; Elsevier Inc.: Amsterdam, The Netherlands, 2019; Volume 2, pp. $202-210$.

16. Resconi, V.C.; Escudero, A.; Beltran, J.A.; Olleta, J.L.; Sanudo, C.; Campo, M.D. Color, lipid oxidation, sensory quality, and aroma compounds of beef steaks displayed under different levels of oxygen in a modified atmosphere package. J. Food Sci. 2012, 77, S10-S18. [CrossRef] 
17. Taylor, A.; Down, N.; Shaw, B. A comparison of modified atmosphere and vacuum skin packing for the storage of red meats. Int. J. Food Sci. Technol. 1990, 25, 98-109. [CrossRef]

18. Renerre, M. Oxidative processes and myoglobin. In Antioxidants in Muscle Foods; Decker, E., Faustman, C., Lopez-Bote, C.J., Eds.; John Wiley \& Sons, Inc.: Toronto, ON, Canada, 2000; Volume 2000, pp. 113-133.

19. Zakrys, P.I.; Hogan, S.A.; O'Sullivan, M.G.; Allen, P.; Kerry, J.P. Effects of oxygen concentration on the sensory evaluation and quality indicators of beef muscle packed under modified atmosphere. Meat Sci. 2008, 79, 648-655. [CrossRef]

20. Sorheim, O.; Nissen, H.; Nesbakken, T. The storage life of beef and pork packaged in an atmosphere with low carbon monoxide and high carbon dioxide. Meat Sci. 1999, 52, 157-164. [CrossRef]

21. Khliji, S.; van de Ven, R.; Lamb, T.A.; Lanza, M.; Hopkins, D.L. Relationship between consumer ranking of lamb colour and objective measures of colour. Meat Sci. 2010, 85, 224-229. [CrossRef]

22. Cayuela, J.M.; Gil, M.D.; Banon, S.; Garrido, M.D. Effect of vacuum and modified atmosphere packaging on the quality of pork loin. Eur. Food Res. Technol. 2004, 219, 316-320. [CrossRef]

23. Bağdatli, A.; Kayaardi, S. Influence of storage period and packaging methods on quality attributes of fresh beef steaks. CyTA-J. Food 2015, 13, 124-133. [CrossRef]

24. Lagerstedt, A.; Lundstrom, K.; Lindahl, G. Influence of vacuum or high-oxygen modified atmosphere packaging on quality of beef M. longissimus dorsi steaks after different ageing times. Meat Sci. 2011, 87, 101-106. [CrossRef]

25. McMillin, K.W. Where is MAP Going? A review and future potential of modified atmosphere packaging for meat. Meat Sci. 2008, 80, 43-65. [CrossRef] [PubMed]

26. Clausen, I.; Jakobsen, M.; Ertbjerg, P.; Madsen, N.T. Modified atmosphere packaging affects lipid oxidation, myofibrillar fragmentation index and eating quality of beef. Packag. Technol. Sci. 2009, 22, 85-96. [CrossRef]

27. Vaskoska, R.; Ha, M.; Naqvi, Z.B.; White, J.D.; Warner, R.D. Muscle, ageing and temperature influence the changes in texture, cooking loss and shrinkage of cooked beef. Foods 2020, 9, 1289. [CrossRef] [PubMed]

28. Vaskoska, R.; Ha, M.; Ong, L.; Chen, G.; White, J.; Gras, S.; Warner, R. Myosin sensitivity to thermal denaturation explains differences in water loss and shrinkage during cooking in muscles of distinct fibre types. Meat Sci. 2021, 179, 108521. [CrossRef]

29. Vaskoska, R.; Venien, A.; Ha, M.; White, J.D.; Unnithan, R.R.; Astruc, T.; Warner, R.D. Thermal denaturation of proteins in the muscle fibre and connective tissue from bovine muscles composed of type I (masseter) or type II (cutaneous trunci) fibres: DSC and FTIR microspectroscopy study. Food Chem. 2021, 343, 128544. [CrossRef] [PubMed]

30. Stolowski, G.D.; Baird, B.E.; Miller, R.K.; Savell, J.W.; Sams, A.R.; Taylor, J.F.; Sanders, J.O.; Smith, S.B. Factors influencing the variation in tenderness of seven major beef muscles from three Angus and Brahman breed crosses. Meat Sci. 2006, 73, 475-483. [CrossRef] [PubMed]

31. Fu, Q.Q.; Liu, R.; Zhang, W.G.; Li, Y.P.; Wang, J.; Zhou, G.H. Effects of different packaging systems on beef tenderness through protein modifications. Food Bioprocess Technol. 2015, 8, 580-588. [CrossRef]

32. Zakrys-Waliwander, P.I.; O'Sullivan, M.G.; O'Neill, E.E.; Kerry, J.P. The effects of high oxygen modified atmosphere packaging on protein oxidation of bovine M. longissimus dorsi muscle during chilled storage. Food Chem. 2012, 131, 527-532. [CrossRef]

33. Zakrys-Waliwander, P.I.; O'Sullivan, M.G.; Walsh, H.; Allen, P.; Kerry, J.P. Sensory comparison of commercial low and high oxygen modified atmosphere packed sirloin beef steaks. Meat Sci. 2011, 88, 198-202. [CrossRef] [PubMed]

34. Bao, Y.L.; Ertbjerg, P. Relationship between oxygen concentration, shear force and protein oxidation in modified atmosphere packaged pork. Meat Sci. 2015, 110, 174-179. [CrossRef] [PubMed]

35. Chen, L.; Zhou, G.H.; Zhang, W.G. Effects of high oxygen packaging on tenderness and water holding capacity of pork through protein oxidation. Food Bioprocess Technol. 2015, 8, 2287-2297. [CrossRef]

36. Jongberg, S.; Wen, J.; Tørngren, M.A.; Lund, M.N. Effect of high-oxygen atmosphere packaging on oxidative stability and sensory quality of two chicken muscles during chill storage. Food Packag. Shelf Life 2014, 1, 38-48. [CrossRef]

37. Faustman, C.; Sun, Q.; Mancini, R.; Suman, S.P. Myoglobin and lipid oxidation interactions: Mechanistic bases and control. Meat Sci. 2010, 86, 86-94. [CrossRef] [PubMed]

38. O'Sullivan, A.; Galvin, K.; Moloney, A.; Troy, D.; O'Sullivan, K.; Kerry, J. Effect of pre-slaughter rations of forage and/or concentrates on the composition and quality of retail packaged beef. Meat Sci. 2003, 63, 279-286. [CrossRef]

39. Descalzo, A.M.; Rossetti, L.; Grigioni, G.; Irurueta, M.; Sancho, A.M.; Carrete, J.; Pensel, N.A. Antioxidant status and odour profile in fresh beef from pasture or grain-fed cattle. Meat Sci. 2007, 75, 299-307. [CrossRef]

40. Cieslak, A.; Stanisz, M.; Wojtowski, J.; Pers-Kamczyc, E.; Szczechowiak, J.; El-Sherbiny, M.; Szumacher-Strabel, M. Camelina sativa affects the fatty acid contents in M-longissimus muscle of lambs. Eur. J. Lipid Sci. Technol. 2013, 115, 1258-1265. [CrossRef]

41. Spanos, D.; Torngren, M.A.; Christensen, M.; Baron, C.P. Effect of oxygen level on the oxidative stability of two different retail pork products stored using modified atmosphere packaging (MAP). Meat Sci. 2016, 113, 162-169. [CrossRef]

42. Campo, M.M.; Nute, G.R.; Hughes, S.I.; Enser, M.; Wood, J.D.; Richardson, R.I. Flavour perception of oxidation in beef. Meat Sci. 2006, 72, 303-311. [CrossRef]

43. Morzel, M.; Gatellier, P.; Sayd, T.; Renerre, M.; Laville, E. Chemical oxidation decreases proteolytic susceptibility of skeletal muscle myofibrillar proteins. Meat Sci. 2006, 73, 536-543. [CrossRef] [PubMed]

44. Prache, S.; Schreurs, N.; Guillier, L. Review: Factors affecting sheep carcass and meat quality attributes. Animal 2021, 100330. [CrossRef] [PubMed] 